\title{
The Effect of Social Media Advertisements on Consumption Perception of Adolescents
}

\author{
Kazan H. ${ }^{1}$ \\ Karaman $\mathbf{G}^{2}$ \\ Okdemir $\mathbf{M}^{3}$
}

1 Hüseyin KAZAN. İstanbul Aydın University, (Turkey)

e-mail: kazan.hsyn@gmail.com

2 Gözde KARAMAN. İstanbul Aydın University, (Turkey)

e-mail: gozdekaraman@stu.aydin.edu.tr

${ }^{3}$ Merve OKDEMIR. İstanbul Aydın University, (Turkey)

e-mail: merveokdemir@stu.aydin.edu.tr

\begin{abstract}
The advantages of technology in many areas are also reflected in the advertising and marketing sectors. The interaction provided by the technology is also positively reflected in the buying behavior of consumers. Especially in recent years, social networks have been one of the leading channels where both the environment and the interaction of the users are at the highest level. Networks such as Facebook, Twitter and Instagram, where individuals spend most of their time, affect users in every way. The most important one of these effects is the effect of social media advertisements on individuals' perception of consumption. This forms the focus of the study. Adolescents who are one of those use social networks the most and who are most affected by this use constitute the sample of the study. In this context, it has been tried to determine whether high school adolescents are affected by advertisements in social media usage by using focus group method in Bakırköy in İstanbul. The findings of the study revealed that social media advertising has a significant effect on directing individuals to consumption.
\end{abstract}

Keywords: Social Media, Social Media Advertisements, Adolescents' Perception.

\section{Introduction}

With the developing technology in recent years, the use of internet and, as a result of it, the use of social media networks have become quite widespread. These changes and developments, as they did in the world, also affected Turkey greatly. In the early 2000s, the use of social media networks, which reached large audiences with Facebook, began to take up more space in our lives with the addition of new social media applications.

Unlike mass media such as newspapers, radio and television, social media networks are immediately accepted by the masses due to the reasons such as individuals can establish mutual communication and realize this communication within seconds. Now official agreements, friendships, relationships with the opposite sex, and shopping can be realized through social media networks. The masses have adopted this innovation, which is both fun and facilitates their work to a high degree, and immediately made it a big part of their lives. In fact, the importance of social media networks in individuals' lives has increased so much that individuals have begun to think that they will not live without these applications.

In the early days when we met social media applications, these networks had effects such as making our lives easier and making our daily lives more fun. But recently, both in the universal dimension and when looked at the situation in Turkey; it is seen that social media networks produce not only positive but also negative results in individuals. Social media networks are now making it difficult for individuals instead of making their lives easier. These channels, too, began to be plundered by humans and became available in different ways than the first time they were used. 
Because of their social media practices, individuals have used social media with the intention of reflecting themselves differently than they are and trying to present their lives by decorating them. While the effects of social media networks can be observed very clearly even for adults, it is not overlooked that it has many effects on adolescents trying to complete one of the most critical periods of development. In this period, individuals in adolescence are trying to complete important developmental characteristics such as identity formation, self-perception development and ultimately self-esteem creation. Adolescents who try to complete these tasks are at risk of being affected by all negative content on social media networks. In this period, adolescents may experience problems such as identity crisis, depression, anxiety disorders, sleep disorders and eating disorders. As adolescents can experience these problems by being influenced by many content, they are also affected by advertisements in social media networks. It is seen that as there are adults who buy products, which they do not even need, because of the advertisements in social media networks, adolescents in critical development period can exhibit such purchasing behaviours. In this study, called "The Effect of Social Media Advertisements on Consumption Perception of Adolescents", it is aimed to reveal the effects of social media advertisements on adolescents' perception of consumption.

\section{A General Overview on Adolescence}

Human beings go through different stages of development from birth to death. During these periods, they experience psychological and physiological differences. The periods of human development are generally classified as childhood, adolescence, young adulthood, adulthood and old age. Looking at these developmental periods, adolescence has always been the most noticeable development period due to emotional and psychological tremours (Koç, 2004). In this period, besides sexual and biological developments, changes such as psychological, social, moral and identity development occur in adolescents. In fact, some theorists who think that adolescence cannot be described as a single period have also divided adolescence into sections. "Social scientists who work adolescence often distinguish between early adolescence from 10 to 13 years, middle adolescence from 14 to 17 years and advanced adolescence from 18 to 22 years "(Steinberg, 2017). In another distinction, it also meets the individuals for three terms. It is expressed as the beginning of adolescence in girls between 11-14 and 13-15 years in boys, the middle of adolescence in girls between 15-16 and 15-21 in girls, and the ends of adolescence 17-21 years in boys and 16-21 in girls (Koç, 2004). "Adolescence is a period of transition from a life lived as a child to a life lived by an adult" (Smith, 2017). Beginning with the physiological development of the genital organs, the period between the reaching puberty and adulthood is the new age of adolescence. Adolescence is an intermediate period between childhood and adulthood. The word youth can also be used instead of adolescence. Puberty is the period of biological-sexual development in early adolescence (Kulaksızoğlu, 2018).

What makes adolescence remarkable, indeed, is that children are expected by the society to make decisions that affect all subsequent periods, even though they have not yet completed childhood. During this period, children are expected to perform difficult tasks such as determining their occupations that they will lead throughout their lives. Familial and social pressures begin on the child who has difficulty in performing these tasks. Becuase of its being an emotionally sensitive period, the child, who has difficulty in fulfilling his/her difficult duties, makes his/her period even more painful. Therefore, these and similar situations lead to consequences such as addiction, aggression and depression in children (Cloutier, 1997). Children, who tend to contradict home and family life, front to the outside world in this period. He/she establishes new friendships, participates in new environments and forms his/her identity. Social media is one of the most effective environments for the socialization and identity formation of adolescents. Adolescents frequently use these environments and shape their environment according to these environments. In this context, it would be appropriate to have a look at the social media usage attitudes of adolescents before looking at the effects of advertisements published in these environments on individuals' perception of consumption.

\section{Attitudes of Adolescents on Social Media}

Turkey's introduction of the Internet dates back to 1990s. The first internet connection was made at Middle East Technical University (METU). In 1997, the National Academic Network (ULAKNET), which provides the internet connection of academic institutions, started to work and universities started to use the internet faster than the first years. In 1999, TTnet emerged. With the emergence of TTnet, the internet has started to spread and be used more rapidly (Arısoy, 2009). With the increase in the prevalence of the Internet, individuals have started to spend more time in these 
environments. Blogs, chat rooms and social networks have become important environments that connect the masses to themselves. Especially in recent years, social networks that have influenced the whole world have become an indispensable part of daily life.

Social media, which has become a medium in itself, is a social internet network established to facilitate people to communicate with each other. While it was a platform that people were not very involved in when it first emerged, now social media has become a platform that is used by almost everyone and even its usage has decreased to a very young age. The purpose of the use of social networks has ceased to be just communication, it has become an area where people manage their lives, allow them to do all their work quickly, determine a social status and even make money (Sarıkaya, 2016). This is because the number of users using the Internet and browsing the social networks accordingly increases day by day.

The number of the Internet users is increasing every year. Conducted researches show that more than one million people are online every day since January 2018. Data from the analyzes show that there are 5.11 billion unique mobile users. In 2019, there is a significant increase compared to the data in January 2018. In January 2019, 3.26 billion people used social media with mobile devices, and it represents an increase of more than 10 percent annually as approximately 297 million new users (We Are Social, 2019). Undoubtedly, there are different reasons for individuals' desire to be more and more in these environments.

When we look at the use of social media, it is seen that there is an effort to prove one's self. Reaching a very high number of followers and being called as "phenomenon" is very common in today's children. For this, they share almost everything they do in these environments. Shares made to become popular often bring along being imitated. The cities they visit, the clothes they wear and even the food they eat are beginning to be imitated. This causes individuals to transform their self with the artificial popular identities imposed here. With this opportunity, users with high numbers of followers began to monetize this activity in the media by being in contact with advertisers.

Today, social media's being on the everyone's lips from seven to seventy, makes these channels a part of our lives. This situation led to the increase in the attitudes and tendencies of adolescents towards social media, too. It was determined in the researches that children and adolescents between the ages of 8 and 18 spend an average of 8 hours a day on technological devices (Cömert, 2010). The fact that young people in the age of upbringing spends time in a virtual environment in the center of their lives brings many negativities. Parents should overdo and spend time for adolescents who do not yet have personality and behavioral patterns. Because in this period, children are curious by nature and desire to belong to a community. Therefore, when the child realizes that there is a community in the world in which he/she dives, wondering what is in this curious situation, he/she wants to enter this world more. When these situations occur, it becomes impossible to keep the child out of it. If the correct communication with the child is not established and there is not enough time for this situation, it is difficult to prevent the 'addiction' situation which is the first in the damages of social media (Downshire, 2018).

Another of the most important effects of adolescence is to try to be included in the perception of beauty in social media, which develops with the desire to get away from the family and to be included in peer groups. Children, who do not use social media and cannot be included in the popular culture and beauty concept of that period, are excluded by peer groups and this may form the basis of various psychological concussions in children. The most prominent of these concussions is 'social anxiety' that develops with peer bullying (Çivilidağ, 2013). Social anxiety is also one of the damages of social media. Under the influence of social media, the child rejects a face-to-face communication. The child, who sees that he/she can easily communicate without being face to face on the Internet, will want to be in this situation even further. This virtual communication weakens the child's ability to communicate and detaches the child from social life. This situation triggers social anxiety in the child (Zorbaz, 2013) and disrupts his personality and makes him addicted to social media. 


\section{Social Media Addiction in Adolescents}

Addiction can be defined as the uncontrollable desire for an object, person or an asset or the state of being under the control of another will (Korkmaz, 2017). Addiction is actually substance addiction that comes to our mind first. Substance addiction is the use of substances derived from mostly from plants to stimulate the consciousness of the human brain. These substances send stimulating signals to the brain at high frequency. When one first experiences this state, he/she tries to experience the pleasure, and thus dependence arises. Addiction is actually a situation in which a person is not satisfied with his/her situation but feels a desire that he/she cannot resist (Gürcan, 2010). Addiction was first included in the DSM-II under the title "Personality disorders and psychotic disorders" as alcoholism and substance addiction. Addiction was first included solo in a single classification in DSM-III (Kring, 2017). In today's addiction types, there is an extremely broad categorization. Substance addiction, alcohol addiction, internet addiction, speed-adrenaline addiction, gambling addiction are some of the common mental and psychological addictions.

As seen above, there are many biological, psychological and physiological types of addiction. In people who are addicted to anything, attitudes and behaviour follow the same patterns. The first option is 'If I want to leave, I will leave' stereotype sentence. They always console themselves in this way even though they know they can't. The second one is 'I cannot stop myself from doing this'. The addicted person cannot live his/her satisfaction against what he/she is addicted after a while. However, they cannot prevent the effort to reach saturation (Korkmaz, 2017). This turns individuals from a healthy personality into diseased individuals.

The fact that technological tools testify to every stage of the life of individuals and reach everything and everywhere, so to speak, with internet connection reveals the internet addiction which is described as the plague of the age. Internet addiction can be described as, in general, not being able to prevent the excessive use of the Internet, the time's which is spent without being connected to the Internet losing its importance, excessive lack of nervousness and aggression when deprived of the person's work, and deterioration of the individual's social and familial life (Arısoy, 2009). The environment and interactions provided by the Internet ties individuals to itself away from real life.

While peer acceptance and social approval stand out in adolescence, the internet offers adolescents the opportunity to meet these expectations through communication applications such as e-mail, instant messaging, logging and chat rooms. Adolescents can easily obtain approval and acceptance in their communication over the internet. Satisfaction from communication via the Internet has been found to increase the susceptibility to the Internet addiction (Kaygusuz, 2013). In their screening study on adolescents between the ages of 10 and $17,25 \%$ of internet users developed friendships over the internet and 14\% found close friendships or romantic relationships (Esen, 2010). The fact that the Internet gives freedom to conceal their real identities allows adolescents to reveal the identity they want to be. This is seen as an important reason for adolescents to use the internet extensively (Alican, 2013). Adolescents' sense of identity, resulting from more satisfaction in the virtual world than in the real world, gives adolescents the opportunity to recognize their characteristics. However, it is not always possible to transfer these experiences to the real world. If this situation is determined by peer groups, they expose each other to ruthless and strict criticism (Esen, 2010). The results of this effect may result in even greater negativities especially in the use up to the addiction level.

Social networking sites, which are the most important components of social media, are defined as virtual communities where users can create individual profiles, interact with their friends and meet other people (Kuss and Griffiths, 2011: 3529). The fact that individuals have a pleasant time during this togetherness increases the time spent on social networks. The advanced dimension of this process is expressed as social media addiction (Aktan, 2018). Social media addiction psikolojik is a psychological problem that develops through cognitive, affective and behavioral processes and causes problems such as occupation, mood regulation, repetition and conflict in many areas of the daily life such as private, business / academic and social life" (Tutgun-Ünal, 2015: 93). Social media addiction has created symptoms where reality and fiction are replaced, virtual world is preferred to real world, real friendships are overshadowed by social friendships, social media communication is preferred to face-to-face communication, and consumer society is triggered. 
Just like substance addiction, social media addiction includes experience of mood modification, specificity (behavioral, cognitive and emotional occupation) classic" symptoms of addiction, which involves the intervention of social networking sites in a positive change of emotional states (Kuss and Griffiths, 2011: 3530). The most important result of social media addiction, which has many negative effects, is that it triggers the consumption habits that constitute the main theme of the study. Social networks, which have left the population of many countries behind, have turned into channels that increase the appetite of advertisers. In this context, most of the advertising budgets are now spent on social media. Because now it is the time of individual marketing and individual advertising. One of the most effective channels for these activities is social networks.

\section{Effects of Social Media Usage on Purchasing}

Today, rapidly developing internet networks and social media managed to influence significantly the personal and psychological fields as well as the sales and marketing areas. With the development of social media, digital advertising and marketing have increased the importance given to social media advertising to a large extent (Çelik, 2014). Messages on social media are multi-faceted and they are created by people such as marketing employees, influencers, individuals, consumers, and so on. Social media is not the unilateral spread of messages to the masses, but the realization of mutual dialogue between individuals (Barutçu, 2013). This is the way that brands follow in the context of sales and marketing, especially through social media. Increasing customer loyalty by interacting with the consumer has become an important criterion of social media marketing. Children and adolescents are the groups most affected by social media, where almost every segment is a densely virtual resident.

The rate of 0-14 age group defined as child population was determined as $23.5 \%$ in 2018 . (Nüfus Projeksiyonları 2018-2080, 2018). The trends of the young population, which affect a significant portion of the population, affect the course of the whole country and their influence in the family. Social media, which is one of the most important tendencies of the young population, has affected adolescents in every area and has managed to determine purchasing tendencies significantly. The adolescents most exposed to social media advertisements have also increased their awareness. Today's children have more personal power than any generation has ever had (Lindsrom, 2003). This power does not always breed positive effects. The process that deals with the acquisition of children as consumers is called 'consumer socializationé (Südaş, 2015). Consumer socialization refers to the process by which people communicate with other consumers and learn knowledge, skills and attitudes (Südaş, 2015). This process has become a rapidly growing medium for the sales and marketing sector.

Under the influence of popular culture, they intervene beyond the needs of the family, the needs of the house and even the car they want to have. Realizing this power, it has directed the advertising and marketing activities towards this field and applied various methods to increase its effect. Today, it is seen that children adolescents aged 3-17 spend more than $\$ 50$ billion annually for their personal needs and entertainment. In addition, it was found that consumption rates of children in this age group were estimated to be 340 billion dollars when they go out with their families (www.mediafamly.org, 2019). According to the definition of Marketing Institute; "It is the management process responsible for defining, identifying and profitably predicting consumer needs" (Terkan, 2014). The sellers, who see the effect of children in the market, take this into consideration and try to attract the child into the market with various methods. One of the most important impacts is to increase the consumption rates of adolescents by advertising to famous people whom they take role models (Sarıkaya, 2016). Role models are 'individuals with admiration and imitation of the individual, who have individual success and characteristics' (Sarıkaya, 2016). These people can be popular in the arts, sports and politics, as well as in social media. These individuals' lifestyles, clothing styles, nutrition, entertainment culture cause their followers to identify by affecting them. After a certain point, this identification reaches the point where it will serve the consumption culture such as eating what they eat, wearing what they wear, and being in the places they go. The research part of the study focuses on the dimensions of this interaction. 


\section{Findings of the Research}

The method used in the study was focus group interview. For focus group interviews, structured questions were used. Eleven questions prepared to examine the effect of social media use on product purchase in adolescents were asked to students in adolescence selected according to thesuitability which is one of the non-probability sampling methods.

In this study, the data obtained from the students in the focus group discussions were recorded by taking notes. The focus group consists of the tenth and eleventh grade students of a high school in Bakırköy, Istanbul. The sample group of the study consisted of three female group consisting of seven people, three male groups of seven people and mixed groups of seven people. The following questions were directed to these groups as structured in the focus group discussion.

1) What is your purpose of using social media?

2) Which social media network do you use more?

3) What do you think about social media advertisements?

4) Do social media advertisements lead you to buy products? product?

5) Does seeing the same advertisement on all social media platforms affect you to buy that

6) Does introducing /using that product by a famous/famous person on social media affect you to buy that product?

7) Do the application buttons in the social media under the advertisments such as 'Shop now' affect you to buy that product?

8) Does the excess number of likes of the product advertised on social media affect you to buy that product? product?

9) Do the comments made to the product advertised on social media affect you to buy that

10) Does advertising on social media make you buy the product even if you don't need it?

11) Does coming across the advertisement of a product you have previously examined on social media affect you to buy that product?

Female students were coded with 'K' code while male students were coded with 'E' code. In the focus group discussions, students were first asked about their aim at using the social media. Other than one out of sixty-three students who participated in the focus group discussions, they stated that they used social media for entertainment, spending leisure time, watching videos about lessons. Only K5 stated that she used social media to shop because of advertising on social media. The second question asked in focus group discussion is which social media networks students use more often. Instagram is the social media network that students use the most. However, E3, E27, E30, E33, E27, E62 stated that they did not have an Instagram account and instead of Instagram they use social networks such as YouTube. E28 expressed 'I used Instagram in the past, but I turned it off because the content was too meaningless for me'. According to the answers, it is seen that all the participants who do not have an Instagram account are 'males'.

As the third question, students were asked about their thoughts about social media advertisements. Among the participating students K19 commented 'I find it unnecessary except for the help', E34 'those who give these advertisements are wasting money', E35 and K61 'advertisements about my interest attract my attention '. K49 expressed her thoughts as 'I think advertisements sometimes work'. All participants, except those who expressed these ideas, said 'I find it unnecessary, absurd and frustrating', and thus revealed the general response of the groups.

When asked about the effects of social media advertising on product purchase, the participants K45 and E27 replied, 'If products are related to my interest, they affect me'. E23 replied, 'I'm starting to look at the product I see in advertising with a negative bias'. It was observed that all the participant students, except these three different participant interpretations, answered the question fifty-fifty.

Another question posed to the students during the focus group interviews was whether or not the advertisements they saw on social media networks frequently appeared and their shopping were directly proportionate. The students' answers to this question are that encountering the same advertisement often is 'boring and uncomfortable' and it even creates an effect that distances the 
product further. Among the answers obtained from the groups consisting of sixty-three participant students, different answers were obtained from only two participant students. E10 said, 'I wonder and have a look at it now that it is always in front of me'; K14 said 'If it's a product I want, I'm impressed'. When the question 'Does introducing /using that product by a famous/famous person on social media affect you to buy that product?' were asked to the high school students in adolescence, most of the students answered the question that they were affected. One of the participating students, E46, said 'I bought the product that a celebrity had previously promoted'. K48, and E26 summarize the general opinion of the groups with the answers 'I think that if this man uses this it, he knows something, I can get that product'. But K17 and K57 expressed their thoughts as 'It does not sound convincing, I really do not think that celebrities use those products'.

Students were also asked whether the 'shop now 'button on social media networks is effective; they expressed their general opinion that it is positive to have easy access to products with this button. E31 of the students summarized the general view of the participating students by saying 'I think this option is a good idea because it makes things easier for me'.

Another question posed to the students during the interviews is whether the number of likes under advertisements on social media networks affects them in shopping. The opinion of all six-three students who participated in the focus group discussions was that the high number of likes did not lead them to purchase products. While even the K60 said, 'I don't want to buy a product that most people like', E25 reflected the general opinion of the participants with the reply that 'advertisements on social media networks usually have fake followers with false ratings and therefore I think they are not reliable'.

Students have different opinions about advertising on social media networks and comments on products. While E24 says, 'If the comments are good, I get affected and get the product, but if there are bad comments, I stop buying the product', K55 answered the question 'In order that there are a lot of positive comments, I do not buy something that I do not want, but if there are negative comments on a product that I want to buy, it dissuases me from buying it'. With the answers given to this question, it was seen that these participants in adolescence were closer to the situation of giving up a product they wanted to buy because of negative comments'.

The students answered the question 'Does advertising on social media make you buy the product even if you don't need it?' with almost half the opposite answers. While Among the groups in this study, only the female students had a higher rate of 'take' answers to this question; only in groups of male students and mixed groups, the answer 'advertising does not affect me if I do not need' was observed to be more intense. $\mathrm{K} 53$, one of the participating students, replied, 'advertising puts the product in my mind and may cause me to buy it in the future'. It was observed that in the group of mixed participants, thereby female students were affected by the male students, they replied the question that they were less affected by the social media advertisements.

In the focus group discussions, the students were lastly asked the question 'Does coming across the advertisement of a product you have previously examined on social media affect you to buy that product?'. Although K63 replied the question as 'Coming across the advertisement everywhere affects me negatively against the product', the majority of the participants stated that coming across the product, which they searched on the Internet before, on social media advertisements is a convincing way to maket hem buy the product. K44 said, 'If I see the product I have researched before constantly, I will always have the opportunity to examine it, at the end I will be convinced and buy'. E21 gave the answer, 'Because it always comes across me, I feel like I need to buy it eventually and I buy it'.

\section{Conclusion}

Nowadays there are a lot of factors affecting people's consumption expenses and one of these factors is social media network. The main reason why social media networks become effective in consumption is the increase in the number of users every day (Çakır, Abacı \& Ağır, 2016: 1288). Adolescents are the largest representatives of this number. In this research, in the focus group discussions conducted with sixty-three students, it was tried to find out how high school students in adolescence were affected by advertisements on social media networks and whether or not their shopping behaviors changed. The first of the results obtained from the eleven questions asked to the 
participating students is the most popular social media network that students use is 'Instagram'. Of the sixty-three students, only five do not have an Instagram account, and all of them are male. No significant difference was found in the answers given to the questions asked during the interviews in the male or female groups. Only in the answers to the question 'Does advertising on social media make you buy the product even if you don't need it?' different answers were obtained due to gender differences. In the group consisting only of female students, positive answers were given to the question, and in mixed groups and male groups, there was the opinion that an unnecessary product was not purchased due to advertisements on social media'.

It was seen that the number of likes in the advertisements in social media networks did not cause a product buying behavior on the students because they were not found reliable by the adolescent students.

As a result of the interviews, in the first questions, students stated that they found social media advertisements generally unnecessary. Even in some of them, responses gathered that advertisements are rather repulsive. But as the questions progressed, without having any difference between males and females; adolescents turn towards shopping being influenced by famous people, comments made on the product advertisment, coming across a product they searched on the Internet before.

As we have seen in previous researches, in the purchasing behaviors of the adolescents; it is concluded that the advertisements played by famous people and the comments made by other social media users to the products are quite effective. It is seen that adolescents tend to buy the products exhibited in the social media advertisements by celebrities, who adolescents take as role models, regardless of how expensive they are (Sarıkaya \& Barutçu, 2016: 61). The impact of social media networks in the purchasing process has become considerable and users are searching for products or services to be purchased and reviewing the comments of previous users (Battallar \& Cömert, 2015: 46). The comments made on the product advertised on social media do not only have a positive effect. The comments here may cause them to create a negative brand perception about the advertised product (Aytan \& Telci, 2014: 14). As a matter of fact, in this research, the responses received from the participant students in the focus group interviews support previous research results.

As a result of literature review and focus group interviews, it was revealed that social media, which affects individuals in many aspects today, also affects students in adolescence due to advertisements and that it changes the purchasing behavior of these individuals and directs them to purchase products.

\section{References}

[1] Aktan, E. (2018). Üniversite Öğrencilerinin Sosyal Medya Bağımlılık Düzeylerinin Çeşitli Değişkenlere Göre İncelenmesi. Erciyes İletişim Dergisi, 5(4), 405-421.

[2] Alican, C. (2013). Ortaokul ve Lisede Öğrenim Gören Öğrencilerin Sosyal Medya Kullanımına İlişkin Tutumları. Sosyal Bilimler Enstitüsü Dergisi, 1-14.

[3] Arısoy, Ö. (2009). İnternet Bağımlıı̆ı ve Tedavisi. Psikiyatride Güncel Yaklaşımlar Dergisi, (1) $1,55-67$.

[4] Aytan, C. \& Telci, E.E. (2014). Markaların Sosyal Medya Kullanımının Tüketici Davranışı Üzerindeki Etkisi. The Turkish Online Journal of Design, Art and Communication, 4 (4), 1-15.

[5] Barutçu, S. Toma, M. (2013). Sürdürülebilir Sosyal Medya Pazarlaması ve Sosyal Medya Pazarlaması Etkinliğinin Ölçümü. İnternet Uygulamaları ve Yönetimi Dergisi, 4(1), 1-19.

[6] Battallar, Z.\& Cömert, M. (2015). Tüketicilerin Tercihlerinde Sosyal Medyadaki Reklamların Etkisi. Turizm Akademik Dergisi, 2 (1), 39-47.

[7] Cloutier, R. (1997). Ergen Psikolojisinde Kuramlar. Ankara Üniversitesi Eğitim Bilimleri Fakültesi Dergisi, Cilt 27, Sayı 2, 875-904.

[8] Cömert, I. T. (2010). Çocuk ve Ergenlerde İnternet Kullanımı. Çocuk Dergisi, (10)4, 166-170.

[9] Çakır, M. Abacı, H. \& Ağır, S.D. (2016). Sosyal Medyanın Tüketici Davranışları Üzerine Etkisi: ADÜ Nazilli İiBF Öğrencilerine Yönelik Bir Uygulama. Eurofe 2016 Bildiri Kitabı 1.Kitap, 12661290. 
[10] Çelik, S. (2014). Sosyal Medyanın Pazarlama İletişimine Etkileri. Erciyes İletişim Dergisi, (3)3, 28-42.

[11] Çivilidağ, A. (2013). Gelişim Süreci Odağında Ergenlik Psikolojisi. Ankara: Nobel Kitabevi, İstanbul.

[12] Downshire, J. (2018). Ergenlerle İletişim Sanatı . İstanbul: Türkiye İş Bankası Kültür Yayınları.

[13] Esen, E. (2010). Ergenlerde İnternet Bağımlıı̆ını Yordayan Psiko-Sosyal Değişkenlerin İncelenmesi. Türk Psikolojik Danışma ve Rehberlik Dergisi, (4)36,127-138.

[14] Gürcan, N. (2010). Ergenlerin Problemli İnternet Kullanımları İle Uyumları Arasındaki Illişkinin incelenmesi. Yayınlanmamış Doktora Tezi, Selçuk Üniveristesi Eğitim Bilimleri Enstitüsü, Konya.

[15] Kaygusuz, C. (2013). İnternet Bağımlıı̆ı̆ı Sorunlar ve Çözümler. Anı yayınları. Ankara.

[16] Koç, M. (2004). Gelişim Psikolojisi Açısından Ergenlik Dönemi ve Genel Özellikleri. Erciyes Üniversitesi Sosyal Bilimler Enstitüsü Dergisi, 1(17), 231-238.

[17] Korkmaz, Y. (2017). Ergenlerde İnternet Bağımlıı̆̆ının Depresyon ve Anksiyete Üzerine Etkisi. Gece Kitaplığı. İstanbul.

[18] Kring, A. (2017). Anormal Psikoloji. Nobel Kitabevi. Ankara.

[19] Kulaksızoğlu, A. (2018). Ergenlik Psikolojisi. Remzi Kitabevi. İstanbul.

[20] Kuss, D. J. and Griffiths, M. (2011). Online Social Networking and Addiction-A Review of the Psychological Literature. International Journal of Environmental Research and Public Health (8), 3528-3552.

[21] Lindstrom, M. (2003). Günümüz Dünya Çocuklarının Satınalma Güçleri. Tüketim Tercihleri ve Markalarla Olan İlişkileri. Csa Yayınları. İstanbul.

[22] Sarıkaya, N. (2016). 11-14 Yaş Arası İlk Dönem Çocuk Ergen Tüketicilerin Alişveriş Davranışlarında Ünlü Kişi Etkisi. Pazarlama ve Pazarlama Araştırmaları Dergisi, (17), 43-64.

[23] Smith, P. K. (2017). Ergenlik. Türkiye İş Bankası Kültür Publishing. İstanbul.

[24] Steinberg, L. (2017). Ergenlik. İmge Kitabevi. Ankara.

[25] Südaş, H. D. (2015). Sosyal Ağlarda Tüketim Temelli Akran İletişiminin İncelenmesi: Adana İlinde Bir Uygulama. Akademik Sosyal Araştırmalar Dergisi, (3)15, 309-327.

[26] Terkan, R. (2014). Sosyal Medya ve Pazarlama: Tüketicide Kalite Yansıması. Organizasyon ve Yönetim Bilimleri Dergisi. (6)1, 57-71.

[27] Tutgun, Ünal, A. (2015). Sosyal Medya Bağımlıı̆ı̆: Üniversite Öğrencileri Üzerine Bir Araştırma. Yayımlanmamış Doktora Tezi, Marmara Üniversitesi Sosyal Bilimler Enstitüsü, İstanbul.

[28] TÜİK. (21.02.2018). Nüfus Prejeksiyonları 2018-2080. http://www.tuik.gov.tr/PreHaberBultenleri.do?id=30567.

[29] We Are Social. (30.01.2019). https://wearesocial.com/blog/2019/01/digital-2019-globalinternet-use-accelerates.

[30] Zorbaz, O. (2013). Lise Öğrencilerinin Problemli İnternet Kullanımının Sosyal Kaygı ve Akran İlişkileri Açısından İncelenmesi. Yayınlanmamış Yüksek Lisans Tezi. Hacettepe Üniversitesi Sosyal Bilimler Enstitüsü. Ankara.

[31] Mediafamily. (30.01.2019). http://www.mediafamily.org/activitiesandquizzes/novactivity.shtml. 